\title{
Boosting of Indian Agriculture through Agritech Startups - An Overview
}

\author{
G. P. Meena ${ }^{1 *}$, R. L. Meena ${ }^{2}$ and Dinesh Kumar ${ }^{3}$ \\ Department of Agricultural Sciences, Jaipur National University, Jaipur (Raj.)-302017, India \\ *Corresponding author
}

\section{A B S T R A C T}

\section{Keywords}

Agriculture,

Agritech, Income,

Startups

Article Info

Accepted:

07 November 2019

Available Online:

10 December 2019
The Oxford Dictionary defines startup as "a newly established business" while according to Merriam-Webster, startup means "the act or an instance of setting in operation or motion" or "a fledging business enterprise". The American Heritage Dictionary suggests it is "a business or undertaking that has recently begun operation." But the question here is what really comes to our mind when you hear the word "STARTUP"? The common answers that which we usually get are influenced by popular media, depicting startup as unsecured job, failed companies, free food, beanbags, Friday beers, open office landscapes and sleeping pods whereas no one recognizes the hard work put on by the guys grinding in their garage. While from the words of Eric Ries, the creator of the Lean Startup Methodology, "A startup is a human institution designed to create a new product or service under conditions of extreme uncertainty." In a bid to double the farmer's income by 2022, the Government of India is continuously looking for ways to boost agricultural production, food processing and marketing avenues through the integration of latest technologies and innovations; thus creating a huge scope for food and agritech startups in the country (Balaji, 2018). India has made a strong name for itself in the global startup community. India ranks amongst the top five countries in the world in terms of number of startups founded. It is estimated that India houses around 7200-7700 start-ups, creating more than 85,000 employment opportunities. It is projected that the number of startups in India will increase to more than 11,500 by 2020 , with job creation from these entrepreneurs reaching 250-300K by 2020 (NASSCOM, 2018a; FICCI 2018).

\section{Introduction}

Agriculture is one of the important pillars of the Indian economy. According to a report from FICCI, about 54 percent of Indian population depends directly on agriculture and it accounts for around 17.3 percent of GDP (FICCI, 2018). Although, agriculture in India has majorly seen a steady growth in the last few years, not much has been done in encouraging young, fresh and unique innovative ideas in the sector. It was only in 2007, when the era of start-ups saw a boost and things started to change. Young entrepreneurs are now quitting their jobs in IT sectors and MNCs to establish their own startups. These young entrepreneurs are now beginning to realize the fact that investing in 
agriculture is one of the very few safe and profitable businesses (MahyCo, 2018). Agriculture is a crucial sector of our economy and the demand for agricultural products is never expected to reduce.

With 350+ Agritech startups in India, many startups are now targeting for breakeven point as the investors show continuous interest for further rounds of funding.

According to NASSCOM, more than half $(59 \%)$ of the investor funding rounds that took place from 2013-17 was focused on startups in 38 seed stage. It was followed by early stage which occupied 32 percent of the investor funding rounds.

A small percentage of 9 percent of the funding rounds was covered by the startups in the growth stage. It was concluded that more than 90 percent of funding was focused on seed stage and early stage startups which increases focus on quality and scale up.

Currently a clear definition of a 'Startup' does not exist in the Indian context due to the subjectivity and complexity involved. Considering various parameters pertaining to any business such as the stage of their lifecycle, the amount and level of funding achieved, the amount of revenue generated, the area of operations, etc, some conceptual definitions are available in the public domain. These have been sourced and enumerated below to provide an indicative understanding on the space to the reader. The Department of Industrial Policy and Promotion (DIPP) is also working around a clear definition for startups and is expected to make it public in due course.

A startup is a young, dynamic company built on technology and innovation wherein the founders attempt to capitalize on developing a product or service for which they believe there is a demand

\section{Scope for growth}

\section{Policy initiatives}

Indian government aims to build an ecosystem that promotes entrepreneurship at the startup level and has taken a number of initiatives to ensure that the startup businesses get appropriate support.

\section{Make in India}

In September 2014, Prime Minister Narendra Modi introduced a big initiative "Make in India" to promote the manufacturing sector by promoting companies to invest in the sector. The intent of the campaign is to attract foreign investments and encourage domestic companies to participate in the manufacturing thereby contributing to the growth story. The government also took various steps to build a favourable environment to do business in the country. For example, an online system for environment clearances, filling income tax returns and extension of validity of industrial licenses to three years have been put in place.

The government increases the foreign Direct Investment limits for most of the sectors

Protection of the intellectual property rights of innovators and creators by upgrading infrastructure, and using state-of-the-art technology.

\section{Standup India}

The Prime Minister also aims to build systems for enabling startups and wants to make the country as a number one destination for startups. In August 2015, he announced a new campaign "Standup India" to help startups with bank funding and encourage entrepreneurship among the young Indians. He also requested all 1.25 lakh bank branches to fund at least one startup founded by tribals and dalits. 
On 6th January 2016, the Union Cabinet has given approval to Standup India campaign which aimed at promoting entrepreneurship among women and scheduled castes and tribes. Some of the salient features include:

Loans under the scheme would be given for green field projects in the non-farm sector,

Intention of the scheme is to facilitate at least two such projects per bank branch,

The scheme is expected to benefit at least 250,000 borrowers in 36 months from the launch of the Scheme.

It also plans to ease out the existing regulatory regime for startups and is considering extending tax incentives to them. The Department of Industrial Policy and Promotion (DIPP) is currently working around a clear definition for startups to ensure that the regime is available to businesses.

\section{Digital India}

This is an initiative led by the Indian government to ensure that government services are made available to every citizen through online platform. In July 2015, the PM announced the Digital India initiative that aims to connect rural areas by developing their digital infrastructure.

This translates into a huge business opportunity for startups. E-Commerce companies in India are planning to break into India's rural market as a part of the government's Digital India initiative.

In September 2015, PM Modi visited Silicon Valley, US and had meetings with a number of founders of technology firms and industry leaders such as Satya Nadella and Sundar Pichai to talk about his ambitions of developing a better startup ecosystem.
According to NASSCOM startup report 2015, every year more than 800 tech startups are being set up in India. By 2020, a projected 11,500 tech-startups are going to emerge and will employ around 250,000people.

\section{Financial assistance}

In his Union Budget speech for 2015-16, Finance Minister Arun Jaitley announced government's plan to set up Micro Units Development Refinance Agency (MUDRA) Bank and a Credit Guarantee Fund with a refinance capital of INR 20,000 $\mathrm{cr}$ and INR $3,000 \mathrm{cr}$.

In April 2015, the government launched Mudra Bank to boost the growth of small businesses and manufacturing units

The newly Bank would provide a credit facility of up to INR 50,000 to small businesses, loan of up to INR 5 lakh to little bigger businesses and loan of up to INR 10 lakh to the MSME sector

\section{MUDRA scheme}

On 6th January 2016, the Union Cabinet has given approval to the following proposals:

The cabinet has approved the creation of a Credit Guarantee Fund for MUDRA loans

It is expected that the fund will guarantee loans of over INR $1,00,000 \mathrm{cr}$ to micro and small businesses in the first instance

According to the finance minister, the MUNDRA scheme is expected to provide benefits to $1.73 \mathrm{cr}$. People. The fund will guaranteeing loans sanctioned under Pradhan Mantri Mudra Yojanaw.e.f. 08th April'15

The cabinet al., so given its go ahead to convert MUDRA Ltd. into MUDRA Small Industries Development Bank of India 
(SIDBI) Bank as a wholly owned subsidiary of SIDBI.

Additionally, the government has set a target to provide a total loan of INR 1.22 Lakh cr. to promote new entrepreneurs and fund the unfunded businesses with the help of banks

\section{India aspiration fund}

The finance minister also announced the India Aspiration Fund to encourage the startup ecosystem and allocated INR $400 \mathrm{cr}$. to various venture funds.

He also launched another program called SMILE (SIDBI Make in India Loan for Small Enterprises) with an allocation of INR 10,000 cr. The objective of the scheme is to offer soft loans in the form of quasi-equity and term loans on soft terms to MSMEs.

\section{Startup exchange}

The SEBI announced a new set of listing norms for startups, including e-Commerce ventures, planning to raise funding from listing on stock exchanges.

These new norms will provide relaxations in disclosure related requirements, takeover and Alternative Investment Fund regulations for IT, data analytics, intellectual property, biotechnology or nano-technology companies.

\section{Self-utilisation and Talent Utilisation (SETU)}

The government is planning to set up a mechanism called SETU, under the newly formed NITI Aayog, to provide technical assistance and incubation to startups. In 2015 Union Budget, Finance Minister, ArunJaitley, has set aside INR 1,000 crore for support startups.

\section{Role of large businesses}

Big corporates generally focuses on innovation, performance excellence and risk management in order to compete in the dynamic global business environment. Issues related to tightening of research and development budgets, increasing digital disruption and organisational bureaucracy make it difficult for large companies to innovate on their own.

Rising number of corporates are looking in search of diverse information, creative people and processes at the smaller companies or star-ups

Many corporates are now shifting their focus from investments into their own research and development to investments in multiple source of innovation, focusing in particular on technology based startups

Nandan Nilekani is investing US\$ 1-2 mn in startups in many sectors including telecom, aerospace, publishing, logistics etc.

Ratan Tata recently invested an undisclosed sum in Tracxn, a Bengaluru-based startup intelligence firm

Corporates collaborate with other small firms including startups by investing fully or partially to access to their pool of talent, assets and capabilities.

Big firms often look at smaller companies as they are more agile, with less bureaucracy and fewer approvals required to develop innovative products. Startups in India have managed to get funding from various informal channels including corporate, angel/seed or VC funding. There are a few startups with innovative business ideas which have managed to raise funds through "Crowdfunding", where a large number of 
investors contribute capital through various channels including internet, mail-orders, events etc. For example, startups such as Ketto, BitGiving and Wishberry have raised money through this concept. Over the recent years, "Crowdfunding" as a concept has gained popularity globally, however, in India, it is still at a nascent stage and is expected to pick up as a regular funding channel with the increase in awareness.

\section{Possible impact of startup incubators}

Startup incubators are companies that assist new startups in their initial phase of development by providing various services. Incubators share both tangible and intangible resources such as equipment, office space, services such as accounting, computing and legal services. They also assist startups in raising startup capital and perform various networking activities to reduce the financial burdens and resource issue. Incubators help entrepreneurs in building sustainable business environment while benefitting the broader corporate communities.

According to NASSOCM report, there is a 40 percent growth in the number of incubators to reach to approximately 110 in 2015 as against around 80 in 2014.

Approximately 50 percent of total incubators are set up in non-metro cities i.e. outside NCR, Bengaluru and Mumbai to offer.

Growing number of educational institutes have started setting up incubator programmes independently or jointly. Shri Ram College of Commerce, New Delhi for example has set an incubator to help their student in their own startups, VESIT college of engineering has set up an incubation centre with the same objective. Big corporates are also setting up incubator programmes to help startups. Tata Group launched T-Hub, Google, Microsoft Ventures etc.
Tata has come up with country's largest technology incubator centre 'T-Hub' in Hyderabad. Google has come up with a Launch pad accelerator programme for specific to mobile startups in India, Brazil and Indonesia with training and developmental support and upto US\$ 50,000 in equity-free funding. Y-Combinator, a popular incubator in the San Francisco Bay Area has designs to make investments in India in the near future.

\section{Startup funding in India}

\section{Funding based on age of company}

Venture capital invests in both stages of company based on the following criteria:

\section{Early stage}

Includes first or second round of institutional investments into companies:

Average of less than five years old

Not a part of big corporates

Investment amount $<\mathrm{US} \$ 20 \mathrm{mn}$

\section{Growth Stage}

Usually third or fourth round of funding

First or second round of investments for firms with 5-10 years age

Spinouts/carve outs from big corporate

Investment amount $<\mathrm{US} \$ 20 \mathrm{mn}$

\section{Approvals and other regulatory processes}

\section{Single online clearance system}

Prime Minister Narendra Modi plans to bring an online approval window which will provide 
over 200permits required by different industries from various government divisions.

This new system for clearance approval for new entrepreneurs would allow them to apply for and track the status of their applications/license permits online.

Currently, 81 state-level clearances, including land acquisition, setting up a factory are being digitized.

133 clearances that are being granted by other central government divisions, including the home, defence and railway ministry, will come online.

PM is working on taking the online governance systems on the fingers of public through the introduction of mobile phones channel

\section{Simplification of regulatory regime}

The Prime Minister aims to bring India ranking on the ease of doing business to 50 from the current ranking of 142 on the World Bank's index, and is working on to simplifying business processes and regulations.

According to a DIPP official, a government panel is working on a policy that proposes exempting startups from a 22 federal rules and regulations such as:

Proposal includes exemption from company and labour laws until a startups revenue touches to certain level,

Certain tax exemptions for a specified period and

Easing norms for raising capital globally.

\section{Opportunities}

Many agritech startups in India are mainly in marketplace segment where e-commerce companies provide fresh and organic fruits and vegetables procured directly from farmers. Very recently many startups have come up providing innovative and sustainable solutions for farmer's problems. Startups have provided solutions such as biogas plants, solar powered cold storage, fencing and water pumping, weather prediction, spraying machines, seed drills, vertical farming, etc. (Sachitanand, 2018) (Fig. 1 and 2).

\section{Challenges}

\section{World Bank's Report: Doing Business 2016}

India is ranked 130th out of 189 economies on the ease of doing business, 133rd on the ease of trading across borders and157th on the ease of paying taxes. India is ranked 155th in case of starting a business

On an average, Indian businesses need to make 33 tax payments annually with around 243 hours spent to prepare and paytaxes in a year

In contrast, China requires just nine tax payments annually, while the US doesn't trouble its taxpayers more than 11timesannually for tax payments. Among South Asian economies, India made the biggest improvement in business regulation, increasing its distance to frontier score

\section{Startup business challenges}

\section{Culture and awareness}

The Indian culture has conditioned people to look down upon failure. For failures, opinions do come by but encouragement rarely so. Entrepreneurship is often about failing and learning from those failures and starting all over again. People need to start accepting failures and allow second chances. Most common questions for anyone to become an entrepreneur 
What to do: problem related to creating a business idea, finding business opportunity or having a vision

Why to do: issues related to reward/incentive analysis, risk evaluation or any other benefits

How to do: issues related to legalities and requirements such as clearances, licenses, approvals required.

Issues related to resource availability including finances, technology and manpower supply

Most people think that having a domain name, setting up a website, moving to social media are complex, costly and time consuming

People are conscious about risk and rewards, and India is referred to as a price sensitive market

People at large are unaware about how they can contribute to economic growth, generate employment and contribute to social development.

\section{Social issues}

Mentorship/Guidance: Most founders of failed startups feel that the lack of proper guidance and mentorship is a major reason behind their failure.

An important factor behind failures and slow growth of some organisations is the lack of quality mentorship, especially in terms of industry knowledge/support. Market structure: Indian markets are largely unorganised and fragmented that create a roadblock for a startup to succeed

\section{Consumer behavior}

Behaviour of Indian consumer changes in every $30-50 \mathrm{~km}$ that makes it really difficult for a startup to create business or market strategy for their products or services. Most startups generally get stuck in stagnancy and gradually shut down.

\section{Location}

An important problem faced by startups is related to location of their business. India is a place of varied culture and taste and thus every product might not be welcomed equally in every region.

\section{Technology}

\section{Technology infrastructure}

Appropriate IT-infrastructure has become a need for Indian businesses given the growing number of consumers online

It is absolutely vital for new startups to train their employees for handling critical customer information such as that of credit card numbers and related data

\section{Cyber security}

Most startups have a B2B business model. This is where cyber risk may rise as they are not aware of potential risks that might exist for their startup business

No back-up plan to keep the startup company running when an accident destroys some key equipment in their data centre.

\section{Financial issues}

\section{Operational finance}

Most startups are self/family funded with limited workforce which makes it difficult to maintain records both financial and perational. Flawed business models and lack of innovative revenue strategies have led to the failure of many startups and they are forced to shut down operations. 
Overcoming unnecessary business steps to manage business operations.

\section{Funding/Capital deficiencies}

Capital and access to capital has been a perennial problem for startups

Government and private sector investors have set aside funds through investment channels but they are not available for all forms of business. The biggest problem for such organisations has been to attract investors and gain their trust with regard to their mode of operations

In the initial phase of operations, startups do not get funding from banks given no credit history of the firm. In addition, there is limited number of credit rating firms for small and medium sized enterprise.

Despite having raised good investments, startups struggle to survive the competition. Startups are unable to mitigate the gap between burn rate and revenue.

Fig.1 Agritech startup opportunities in Indian agriculture (Kaalari, 2018)

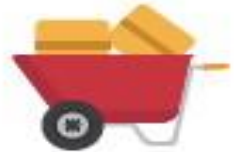

Fintech platforms

Offering applications and platforms that connect farmers digitally and provides them financial, agricultural and government-related services based on their crops and crop cycle

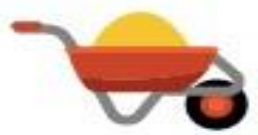

Nano technology

Providing facilities such as use of nanocapsules, nanoparticles and viral capsids to cure diseases, enhancing nutrients absorption by plants

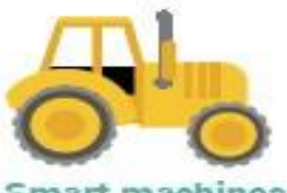

Smart machines

Providing remotely operated machines, operating with greater precision, and performing specific operations using harvesting robots, seeding machines, electrostatic sprayers, etc.

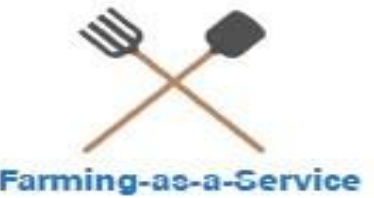

Offering farming services and machinery on rent for reducing capex and increasing affordability

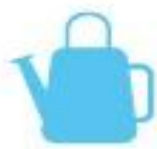

IOT and big clata Facilitating data collection and decision making using drones, sensors, loT technology, and data analytics

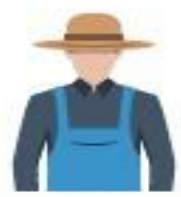

Precision farming

Facilitating application of precise amount of inputs such as water, fertilisers and pesticides, at the right time for increasing productivity

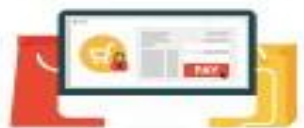

E-commerce and market linkages

Providing platforms to farmers and merchants where they can buy agriculture inputs and sell products without involvement of middlemen

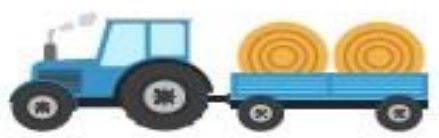

Post harvest technologies Offering technologies and machineries for cleaning. sorting and processing crops at the farm, and cold storage to reduce wastage and increase shelf life of food items 
Fig.2 Key Agritech investors in India

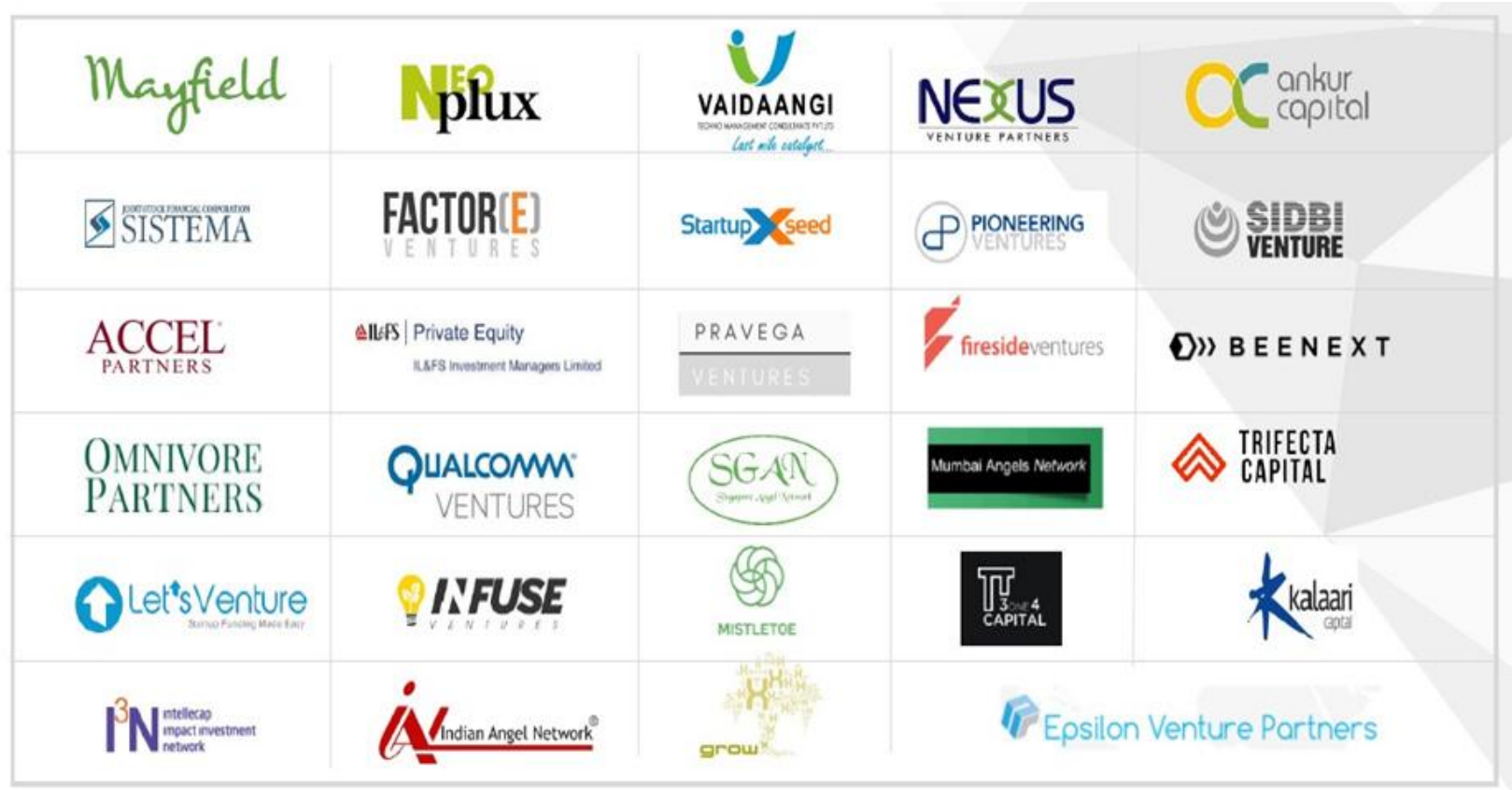

Source: NASSCOM, $2018 b$

\section{Cash flow management}

Effective cash management is an important factor to achieve objectives both short term and long term. Cash is still a preferred option for payments owing to the fact that electronic payment has not achieved complete penetration to Tier 2 and Tier 3 cities-Gap between burn rate and revenue: Given rising competition from peers both from big as well as small, it becomes imperative for startups to scale up the business and require external funding for the sustainability/growth in the market.

Evolution on the basis of funding: Mega funding and mega announcements have become a thing of the past, post consolidation on a large scale across the sector over the last few years. Both the investor and the entrepreneur are now more consciously focusing on innovation, capital efficiency and client/customer satisfaction, a view which is bound to impact the funding scenario henceforth.

\section{Sustainability issues}

The level of knowledge that business advisers have about ecological issues and their willingness to discuss this with their clients is important in creating business ventures.

Lack of information - provision of more information directly to business founders could help in the adoption of more sustainable business practices.

Not aware of potential that might exist for their startup business.

Role of public funding in promoting sustainable enterprises is often overlooked.

\section{Regulatory issues}

Multi window clearances: Budding entrepreneurs have to make multiple trips to government offices to register and seek clearances. Urgent need to scrap multiple regulatory clearances 


\section{Taxation issue}

Taxes like octroi, VAT, excise creates problems for entrepreneurs while starting up a business. NASSCOM has batted for the exemption of both direct and indirect taxes for all startups in India

Taxation is a barrier for technology adoption and proves to be an immense hurdle for budding entrepreneurs

With taxation out of the way, startups will be able to stem the cash outflow.

\section{References}

Balaji S (2018) India's farmers could be making more money soon, with the help of clever agritech startups. Retrieved from https://www.forbes.com/sites/sindhuja balaji/2018/03/19/indias-farmerscould-be-making-more-money-soonwith-the-help-of-clever-agritech- startups/\#5cedc4bd7abe.

FICCI (2018) Agri start-ups: Innovation for boosting the future of agriculture in India. Retrieved from http://ficci.in/publication.asp?spid=230 49.

MahyCo (2018) how are agri startups helping India grow? Retrieved from https://mahyco.com/how-are-agristartups-helping-india-grow/

NASSCOM (2018a) Indian tech start-up ecosystem 2018: Approaching Escape Velocity. Retrieved from https://www.nasscom.in/knowledgecenter/publications/indian-tech-startecosystem-2018-approaching-escapevelocity.

Sachitanand R (2018) For India's agri-tech startups, the wind of change is finally here.

Retrieved fromhttps://economictimes.indiatimes. com/small-biz/startups/features/forindias-agri-tech-startups-the-wind-ofchange-is-finallyhere/articleshow/64714325.cms

\section{How to cite this article:}

Meena, G. P., R. L. Meena and Dinesh Kumar. 2019. Boosting of Indian Agriculture through Agritech Startups - An Overview. Int.J.Curr.Microbiol.App.Sci. 8(12): 396-405. doi: https://doi.org/10.20546/ijcmas.2019.812.053 